Int. J. Dev. Biol. 50: 377-384 (2006)

doi: $10.1387 / \mathrm{ijdb} .052085 \mathrm{sr}$

Original Article

\title{
BMP2/4 and BMP5-8 in jellyfish development and transdifferentiation
}

\author{
SUSANNE REBER-MÜLLER\#, RUTH STREITWOLF-ENGEL\#, NATHALIE YANZE\#, VOLKER SCHMID, \\ MICHAEL STIERWALD, MICHAEL ERB and KATJA SEIPEL* \\ Institute of Zoology, University of Basel, Biocenter/Pharmacenter, Basel, Switzerland
}

\begin{abstract}
Bone morphogenetic proteins (BMPs) have key roles in gastrulation, mesoderm induction and axial patterning. The multitude of bilaterian BMPs employed in these morphogenetic processes contrasts starkly with the scarcity of BMPs in Cnidaria, the most basal eumetazoan phylum. In coral, sea anemone and hydra species, BMPs have been found to be associated with larval and polyp axial patterning. In the hydrozoan jellyfish Podocoryne (Hydractinia) carnea the $B M P 2 / 4$ and BMP5-8 genes are expressed unilaterally in the larva, corroborating a possible role in larval axial development. With the focal area of $B M P$ expression in the anterior region, however, the jellyfish larva may have a developmental reversal of spatial polarity compared to the anthozoan larva. In medusa development, BMP genes are expressed in divergent expression territories within the presumptive radial canals and in various parts of the endoderm, indicative of an involvement in mesoderm patterning and gastrovascular system formation reminiscent of bilaterian BMP functions. In addition, the BMP2/4 and BMP5-8 genes may play roles in wound response and dedifferentiation or S-phase re-entry, respectively, as the former is expressed in striated muscle cells immediately after excision from the bell and the latter in the initial phase of muscle cell transdifferentiation.
\end{abstract}

KEY WORDS: axis, BMP, development, jellyfish, transdifferentiation

\section{Introduction}

The largest subgroup of the TGF $\beta$ superfamily of secreted signalling molecules is the bone morphogenetic protein (BMP) family (Zhao, 2003). Apart from osteogenesis BMPs regulate many important developmental events including gastrulation, mesoderm induction, dorso-ventral patterning, left-right asymmetry, neural patterning, skeletal and limb development, organ formation and gametogenesis. The BMPs, like all TGF $\beta$ s, are synthesized as proproteins that are processed to release the mature ligand characterized by seven highly conserved cysteine residues. The mature peptide is folded into a typical structure termed the cysteine knot (Kingsley, 1994). Homo- or heterodimerization of mature peptides yields the bioactive compounds. Signalling is mediated by two types of homologous integral receptor serine-threonine kinases that hetero-oligomerize after ligand binding and transduce the signal to downstream intracellular effectors of the Smad protein family (Massagué, 1998). BMPs share a high level of sequence conservation in the mature peptide reflected in the ability to function in cross-phyla experiments (Padgett et al., 1993; Sampath et al., 1993; Hayward et al., 2002).

BMP2/4 orthologs and components of the BMP signal transduction pathway have been recently isolated from the coral Acropora milleporaand the sea anemone Nematostella vectensis (Samuel et al., 2001; Hayward et al., 2002; Finnerty et al., 2004). Additionally, a Smad and two BMP5-8 proteins have been identified in the fresh water polyp Hydra (Hobmayer et al., 2001; Reinhardt et al., 2004). In the evolutionary context the unilateral expression patterns of the cnidarian BMP2/4 and BMP5-8 orthologs have been discussed as regulators of axis formation of a potential bilaterian-like cnidarian ancestor (Hayward et al., 2002; Finnerty et al., 2004).

Unlike the anthozoans and the fresh water hydrozoan Hydra the marine hydrozoan Podocoryne carnea features a complete life cycle. The adult stage is the medusa with the characteristic swimming bell composed of a well developed striated muscle

Abbreviations used in this paper: BMP, bone morphogenetic protein; TGF $\beta$, transforming growth factor beta.

*Address correspondence to: Katja Seipel, Institute of Zoology, University of Basel, Biocenter/Pharmacenter, Klingelbergstrasse 50, $\mathrm{CH}-4056 \mathrm{Basel}$, Switzerland. Fax: 41-61-267-1627. e-mail: Katja.Seipel@unibas.ch

\#Note: These authors contributed equally to this paper. 
tissue coordinated by a simple nervous system, a feeding and sex organ, called manubrium and a gastrovascular system. Both the polyps and medusae of many hydrozoan jellyfish species, including Podocoryne carnea, have excellent regenerative potential. They can replace tentacles and bell tissues, as well as regenerate the feeding and sex organ (manubrium) as well as eyes and statocysts, where present, using differentiated cells as the main cellular source for regeneration.

Here we describe the isolation and characterization of two BMP orthologs, BMP2/4 and BMP5-8 from the jellyfish Podocoryne carnea, with a detailed analysis of the gene expression patterns in the various life stages and during in vitrotransdifferentiation of the isolated striated muscle to smooth muscle and nerve cells.

\section{Results}

\section{Isolation and characterization of jellyfish BMP genes}

The jellyfish BMP2/4 and BMP5-8 genes were isolated by homology PCR. The gene products of 399 and 407 amino acid residues, respectively, are genuine BMP proproteins with struc-

A

\begin{tabular}{ll|llll}
\hline & & C & C C & CC & CC \\
\hline SP & Pro-Domain & Ligand Domain &
\end{tabular}

B

\begin{tabular}{|c|c|c|}
\hline $\begin{array}{l}\text { BMP2/4-Pc } \\
\text { BMP58-Pc }\end{array}$ & $\begin{array}{l}1 \\
1\end{array}$ & 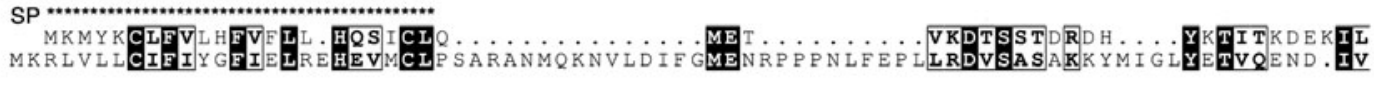 \\
\hline $\begin{array}{l}\text { BMP2/4-Pc } \\
\text { BMP58-Pc }\end{array}$ & $\begin{array}{l}49 \\
80\end{array}$ & 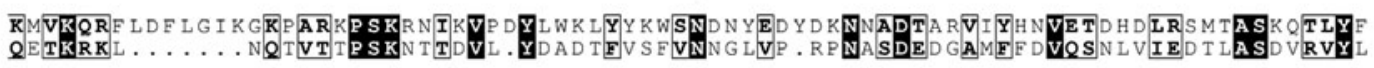 \\
\hline $\begin{array}{l}\text { BMP2/4-Pc } \\
\text { BMP58-Pc }\end{array}$ & $\begin{array}{l}119 \\
151\end{array}$ & 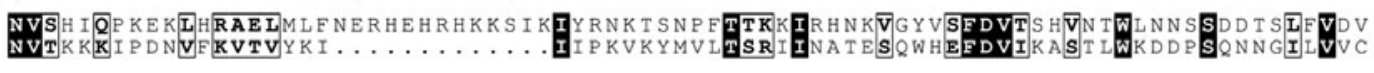 \\
\hline $\begin{array}{l}\text { BMP2/4.Pc } \\
\text { BMP58-Pc }\end{array}$ & $\begin{array}{l}209 \\
218\end{array}$ & 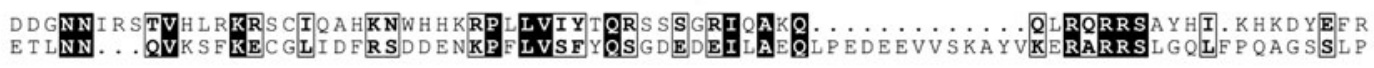 \\
\hline $\begin{array}{l}\text { BMP2/4-Pc } \\
\text { BMP58-Pc }\end{array}$ & $\begin{array}{l}275 \\
295\end{array}$ & 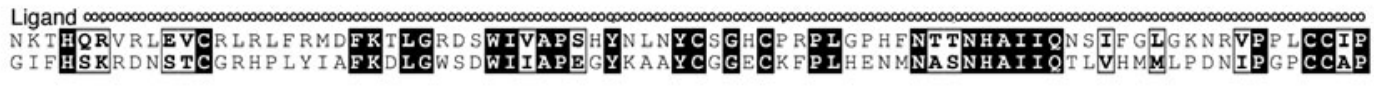 \\
\hline $\begin{array}{l}\text { 8MP2/4.Pc } \\
\text { BMP58-Pc }\end{array}$ & $\begin{array}{l}355 \\
375\end{array}$ & 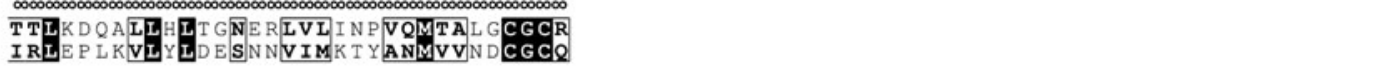 \\
\hline
\end{tabular}

C

BMP3-Hs
DPP-Dm
BMP2/4-Pc
BMP2/4-Am
BMP4-Hs
BMP2-Hs
Gbb-Dm
Scr-Dm
BMP10-Hs
BMP58-Hv
BMP58-Pc
BMP8-Hs
BMP7-Hs
BMP6-Hs
BMP5-Hs
BMP3-Hs
DPP-Dm
BMP2/4-Pc
BMP2/4-Am
BMP4-Hs
BMP2-Hs
Gbb-Dm
Scr-Dm
BMP10-Hs
BMP58-Hv
BMP58-Pc
BMP8-Hs
BMP7-Hs
BMP6-Hs
BMP5-Hs

\begin{tabular}{lll} 
& & \multicolumn{1}{c}{} \\
370 & $\mathbf{C}$ \\
487 & $\mathrm{C}$ \\
286 & $\mathrm{C}$ \\
277 & $\mathrm{C}$ \\
302 & $\mathrm{C}$ \\
296 & $\mathrm{C}$ \\
335 & $\mathrm{C}$ \\
300 & $\mathrm{C}$ \\
323 & $\mathrm{C}$ \\
303 & $\mathrm{C}$ \\
306 & $\mathrm{C}$ \\
301 & $\mathrm{C}$ \\
330 & $\mathrm{C}$ \\
412 & $\mathrm{C}$ \\
353 & $\mathrm{C}$ \\
\hline
\end{tabular}

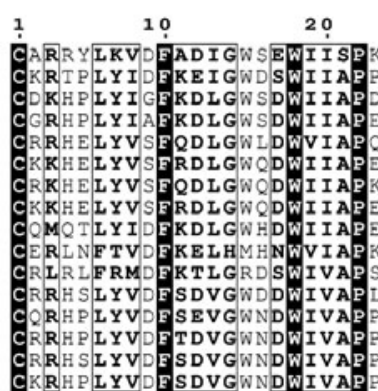
30

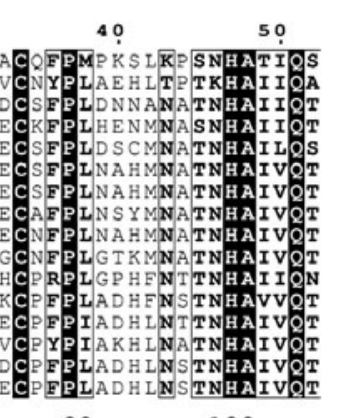
60 70 90 100
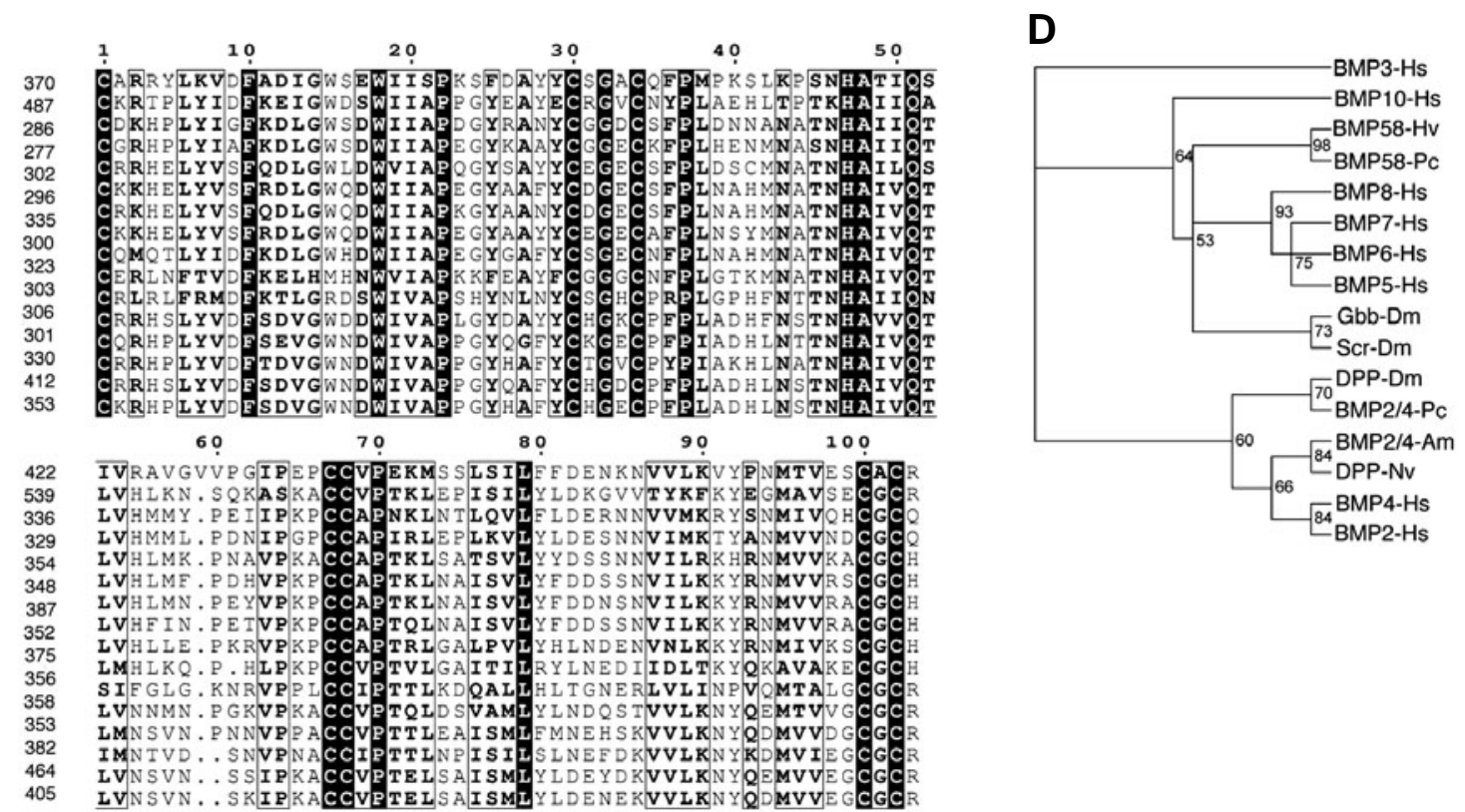

Fig. 1. Conservation of BMP proteins. The BMP proprotein domain structure (A) includes the signal peptide (SP), pro-domain and the mature ligand domain with seven conserved cysteine residues. (B) Full length sequence alignment of the Podocoryne carnea (PC) BMP proproteins BMP2/4 and BMP5-8. The signal peptide and ligand domains are outlined. (C) BMPligand domain sequence alignment. The Podocoryne carnea (PC) ligand domains are compared to representative domains from Acropora millepora (Am), Drosophila melanogaster (Dm), Hydra vulgaris (Hv), Nematostella vectensis (Nv) and human (Hs) BMP proteins. Identical amino acids are boxed in black and similar amino acids are boxed in white when present in more than half of the sequences. The number of the amino acid residue at the beginning of the aligned sequence is indicated relative to the start codon. (D) Phylogenetic analysis of the sequences aligned in (C). BMP3 has been used as outgroup. 


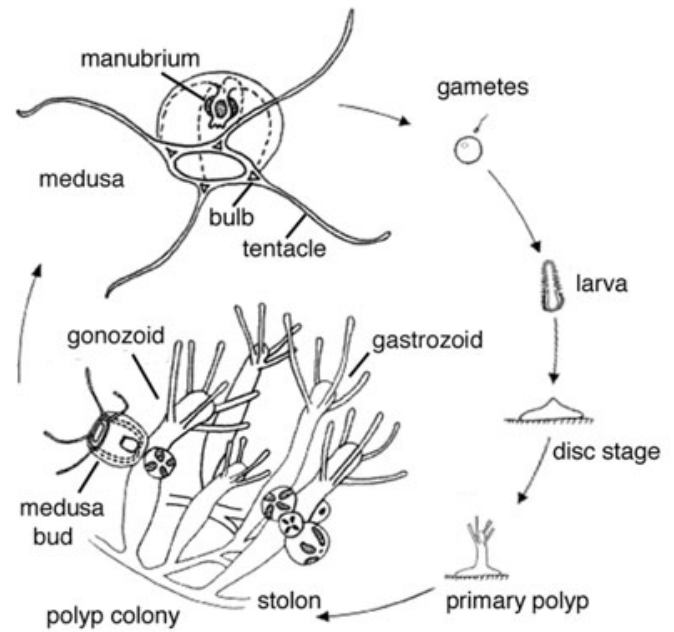

Fig. 2. Life cycle of the jellyfish Podocoryne carnea. The pelagic medusa develops within one week and then detaches from the benthic polyp colonies, consisting of feeding (gastrozoid) and asexually reproducing polyps (gonozoids). The sexually mature medusa liberates gametes. After fertilization the embryo develops within $35 \mathrm{~h}$ into a ciliated planula larva that is ready to attach to the substrate and form the primary polyp.

tural features characteristic for the TGF- $\beta$ superfamily, including a putative signal peptide, a pro-peptide and a mature ligand peptide with an invariant pattern of seven cysteine residues in the carboxy-terminal domain (Fig. $1 \mathrm{~A}, \mathrm{~B}$ ). Both the Podocoryne BMP2/4 and BMP5-8 contain additional cysteine residues not usually found in TGF $\beta$ pro-peptides. The mature BMP2/4 ligand is more related to Drosophila DPP with $48 \%$, than to the Acropora and chordate ligands with $46-47 \%$ identity. Within the propeptide, the similarities are in the range of $26-27 \%$ identity to the Acropora and chordate BMP2/4 orthologs. The mature BMP5-8 ligand and the pro-peptide share $61-65 \%$ and $21-30 \%$ identity, respectively, with the mammalian BMP5 to BMP8 and Drosophila60A/gbb. The phylogenetic analysis of the mature ligand sequences confirms the placement of the PodocoryneBMP proteins within the BMP2/ 4 and BMP5-8 subfamilies of TGF $\beta$ factors (Fig. 1 C,D).

\section{Expression patterns in development}

In most hydrozoan jellyfish species medusa development is indirect and the sessile polyp stage precedes medusa formation. Polyp and medusa differ considerably in life style and morphology (Bouillon, 1993). Podocoryne carnea is a typical member of the Hydrozoa with a metagenic life cycle including a lecitotrophic planula larva, a stationary benthic polyp stage and a free-swimming medusa, the sexually reproducing form (Fig. 2).

$B M P$ gene expression patterns were analyzed in various life cycle stages by in situ hybridization. BMP-specific staining was not detected in early embryos up to the post-gastrula stage (Fig. $3 \mathrm{~A}, \mathrm{~F}) . B M P 2 / 4$ expression is activated in the early planula larva where transcripts localize to the anterior pole, in a unilateral, mostly ectodermal position (Fig. 3B). The unilateral anterior staining reaches maximal levels $28-32 \mathrm{~h}$ after fertilization (Fig. 3C). By the second day after fertilization the focal area of BMP2/ 4 staining has shifted from the unilateral to a frontal position (Fig. 3D). Staining is strongest in the most anterior pole, an area packed with glandular and sensory cells (Bouillon, 1993). Addi- tionally there is a diffuse patchy staining in the larval endoderm. In the three day old larva BMP2/4-specific staining is found exclusively in the larval endoderm (Fig. 3E).

$B M P 5-8$ expression is also activated in the early planula larva where transcripts appear evenly distributed in the endoderm along the anterior-posterior axis (Fig. 3G). In 28-32 hrs old larvae some weak unilateral staining is present in the anterior pole, in a mostly ectodermal position (Fig. $3 \mathrm{H}$ ). In older larvae staining has shifted to the frontal area (Fig. 3l), with maximal intensity in the three day old larva (Fig. 3J). Evidence for BMP expression in the polyps is equivocal with no detectable signal by in situhybridization and low level signal by RT-PCR (not shown).

In the youngest stage of medusa bud formation (stage 1 after Frey, 1968) BMP2/4-specific staining localizes to the bud endoderm (Fig. 4A) and from stage 2 on extends to the endoderm of the radial canal primordia (Fig. 4 B,C). There is no apparent expression in the developing entocodon, a mesoderm-like layer (reviewed in Seipel and Schmid, 2005) and the endoderm of the manubrium anlage. In bud stages 5 to 7 staining is found in the developing radial canals and their distal ends, the tentacle bulbs, with highest intensities in the outer, peripheral endodermal cells of the tentacle bulbs (Fig. $4 \mathrm{G}, \mathrm{H}$ ) and the radial canals (Fig. $4 \mathrm{H}$ ). Additionally there is some weak interradial staining in the manubrial endoderm (arrowheads in Fig. $4 \mathrm{H}, \mathrm{I}$ ). In the late bud stages $B M P 2 / 4$-specific staining is present in the tentacle bulb and manubrial endoderm, with additional prominent staining in the exumbrella (Fig. 4I).

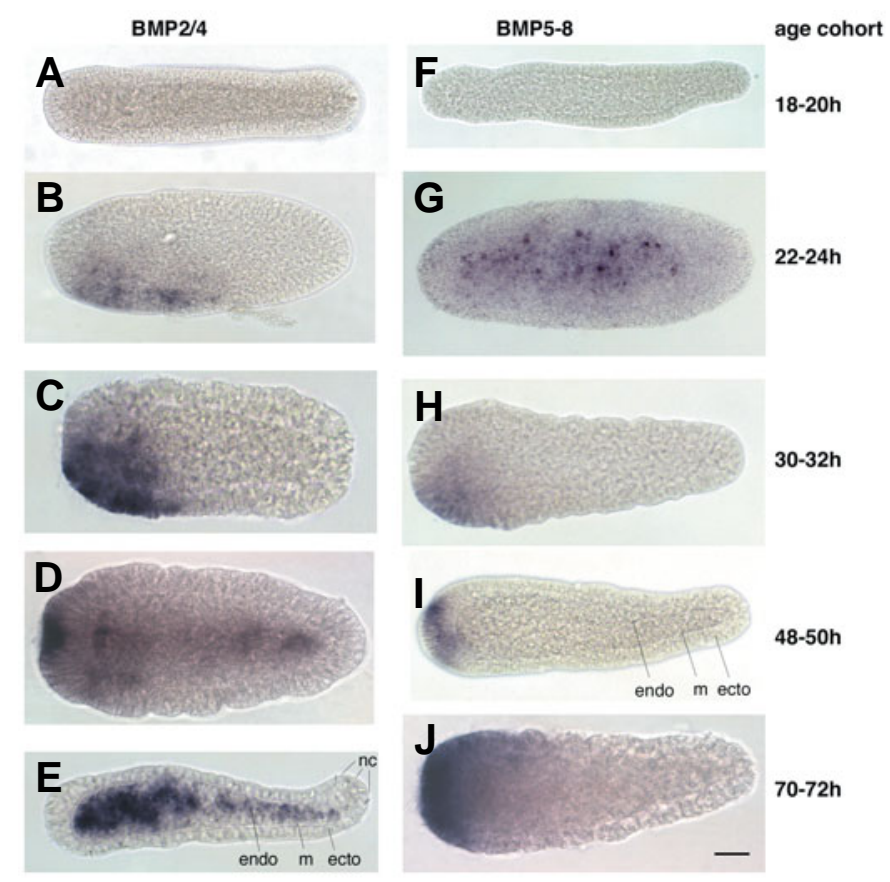

Fig. 3. BMP gene expression in the developing larva. Whole mount in situ hybridization with antisense RNA probes for BMP2/4 (A-E) and BMP5-8 (F-J). Representative larvae have been selected from two hour developmental windows and are positioned with the anterior pole to the left. Representative patterns were found in significant numbers within the age cohorts. Bar corresponds to $50 \mu \mathrm{m}$ in (A-J). ecto, ectoderm; endo, endoderm; $m$, mesoglea; nc, nematocyte capsules. 

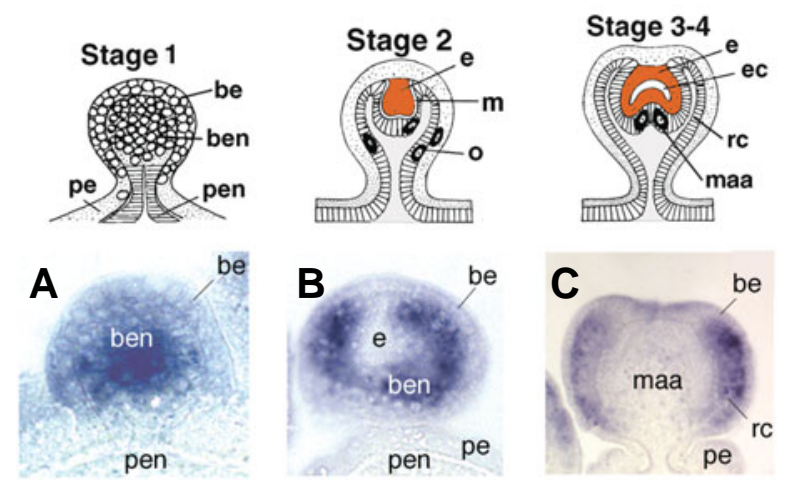

BMP2/4
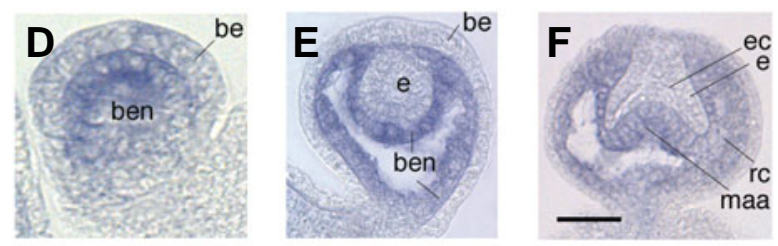

BMP5-8
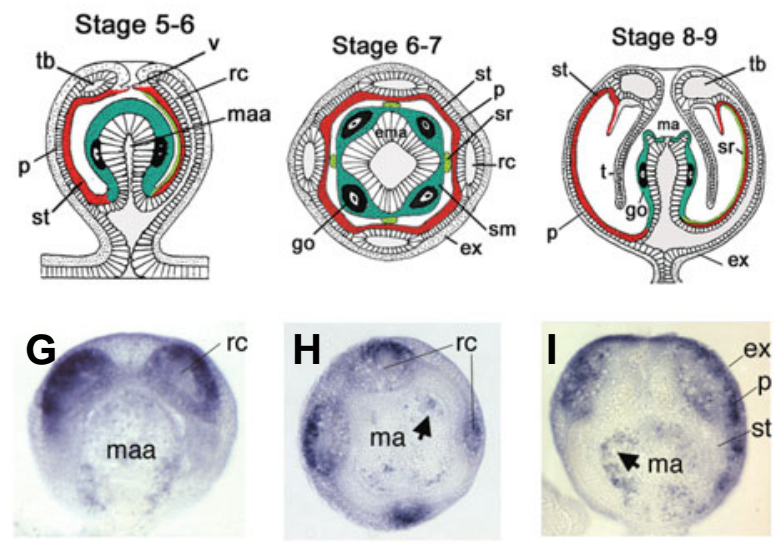

BMP $2 / 4$
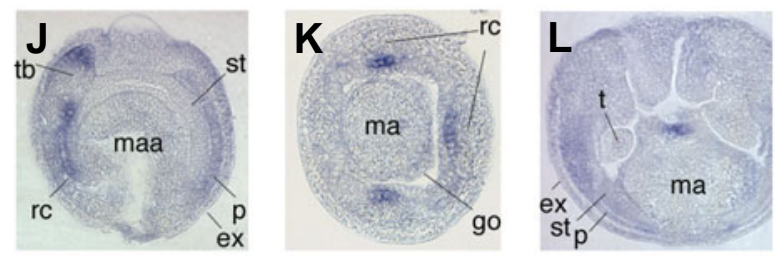

BMP5-8

Fig. 4. BMP gene expression in the developing medusa. In situ hybridization with antisense RNA probe for BMP2,4 (A-C, G-I) and BMP5-8 (D-F, J-L) in medusa bud stages $1(A, D), 2(B, E), 3-4(C, F), 5-6$ $(G, J), 6-7(H, K)$ and 8-9 (I,L). (A-G; I,J,L) Sagittal sections; $(H, K)$, cross sections. Medusa buds were staged according to Frey (1968). Arrows in $(H, I)$ point to staining in the manubrium endoderm. Abbreviations: be, medusa bud ectoderm; ben, medusa bud endoderm; e, entocodon (brown) and the derived striated muscle (red) and smooth muscle (green); ec, entocodon cavity; ema, endoderm of the manubrium; ex, exumbrella; go, gonads; $m$, mesoglea (ECM) separating entocodon from ectoderm and endoderm; ma, manubrium; maa, manubrium anlage; 0 , oocytes; $p$, plate cells of the subumbrella; pe, polyp ectoderm; pen, polyp endoderm; rc, radial canal; sm, entocodon derived smooth muscle of the manubrium (dark green); sr, entocodon derived smooth muscle over the radial canal (light green); st, striated muscle (red); $t$, tentacle; tb, tentacle bulbs; $v$, developing velum. Bar corresponds to $50 \mu \mathrm{m}$ in $(A, B, D) ; 100 \mu \mathrm{m}$ in $(C, E, F)$ and $200 \mu \mathrm{m}$ in (G-L).
While in the initial medusa development the BMP5-8-specific staining localizes to the early bud endoderm (Fig. 4D), the developing radial canals (Fig. 4 E,F) and the tentacle bulbs (Fig. $4 \mathrm{~J}$ ), thus resembling the $B M P 2 / 4$ pattern, in later stages the expression domains diverge with BMP5-8-specific staining at the inner side of the radial canal endoderm, where a small band of three to four BMP5-8-positive cells is located, adjacent to the epidermal lining consisting of striated and smooth muscle (Figs. $4 \mathrm{~J}, \mathrm{~K}, 5)$. In late stages some weak BMP5-8staining localizes to the striated muscle and few cells at the manubrial lips (Fig. 4L). The staining patterns of the jellyfish $B M P$ genes are summarized and put into context together with other developmental regulators for medusa bud stage 6-7 in Fig. 5.

\section{Expression during transdifferentiation}

Many cnidarians, in particular the hydrozoan species, have superb regeneration capacities (Galliot and Schmid, 2002; Holstein et al., 2003). Regenerates are formed by rearrangement of the remaining tissues, by recruitment of undifferentiated cells or by activation of differentiated cells through dedifferentiation and reprogramming, a process called transdifferentiation.

In the hydrozoan Podocoryne carnea striated muscle cells are recruited for medusa regeneration. The tissue located in the subumbrella resembles the bilaterian mononucleated striated muscle in structure and development (reviewed in Seipel and Schmid, 2005). In the experimental setting striated muscle tissue with adhering extracellular matrix (ECM) is isolated from the medusa bell. In the absence of enzymatic treatment the muscle tissue maintains its differentiated and quiescent state. However, when isolated in the presence of collagenase and treated with pronase the striated muscle tissue dedifferentiates, the cells reenter S-phase and differentiate nerve cells or, alternatively, form functional regenerates (Schmid and Alder, 1984; Alder and Schmid, 1987). More accurately the activated striated muscle cells aggregate and transdifferentiate to smooth muscle cells that start to divide asymmetrically producing each one proliferating smooth muscle cell acting as stem cell and a daughter cell differentiating into a RFamide positive nerve cell (Fig. 6A). This well defined system was used to analyse the expression of the jellyfish $B M P$ genes in the process of transdifferentiation.

RT-PCR studies show that the jellyfish BMP growth factors are differentially expressed in the isolated striated muscle (Fig. 6B). Immediately after mechanical isolation expression levels are high for the BMP2/4and low for the BMP5-8gene. When isolated in the presence of collagenase and treated with pronase $B M P 2 / 4$ expression is immediately shut down leading to undetectable levels after two hours and throughout the transdifferentiation process (Fig. 6B). In contrast, BMP5-8 expression is upregulated to maximal levels within 15 minutes followed by a gradual decrease during dedifferentiation and S-phase re-entry (Fig. 6B,C). BMP58 is not expressed during proliferation and differentiation of new cell types (Fig. 6B).

\section{Discussion}

\section{Jellyfish BMP genes in gastrulation and axial patterning?}

Unilateral localization of $B M P$ transcripts, e.g DPP/BMP2/4 in the coral embryo of Acropora (Hayward et al., 2002) and in the sea anemone Nematostella (Finnerty et al., 2004) and of BMP5-8 in 
the Hydra polyp (Reinhardt et al., 2004) has been interpreted as evidence for BMP function in axial patterning and as indication of bilaterian-like dorsal-ventral traits in the cnidarian ancestors. A similar role may pertain to the Podocoryne BMPgenes as they also feature transient unilateral expression in the early planula larva (Fig. $3 \mathrm{C}$ and $\mathrm{H}$ ). However, no dorsal-ventral characteristics have been reported so far in the morphologies of any hydrozoan planula larva. Moreover, unilateral localization of both $B M P$ transcripts is observed in the anterior region of the post-gastrula embryo concurrent to expression of the anterior Hox and ParaHox genes Cnox 1 and Gsx(Yanze et al., 2001), contrasting the patterns in anthozoan embryos, where both the DPP/BMP2/4 and the anterior Hox genes anthox 6 and anthox 2 are expressed at the blastoporal end of the planula (Finnerty et al., 2004). The apparent contradiction may be attributed to divergent modes of development of the hydrozoan and anthozoan planula larvae (Tardent, 1978). While the axial expression of Hox genes remain consistent in the anthozoan larva and primary polyp (Finnerty et al., 2004), the spatial polarity appears to be reversed in the hydrozoan larva to polyp transition (Masuda-Nakagawa et al., 2000). In the developing medusa, however,

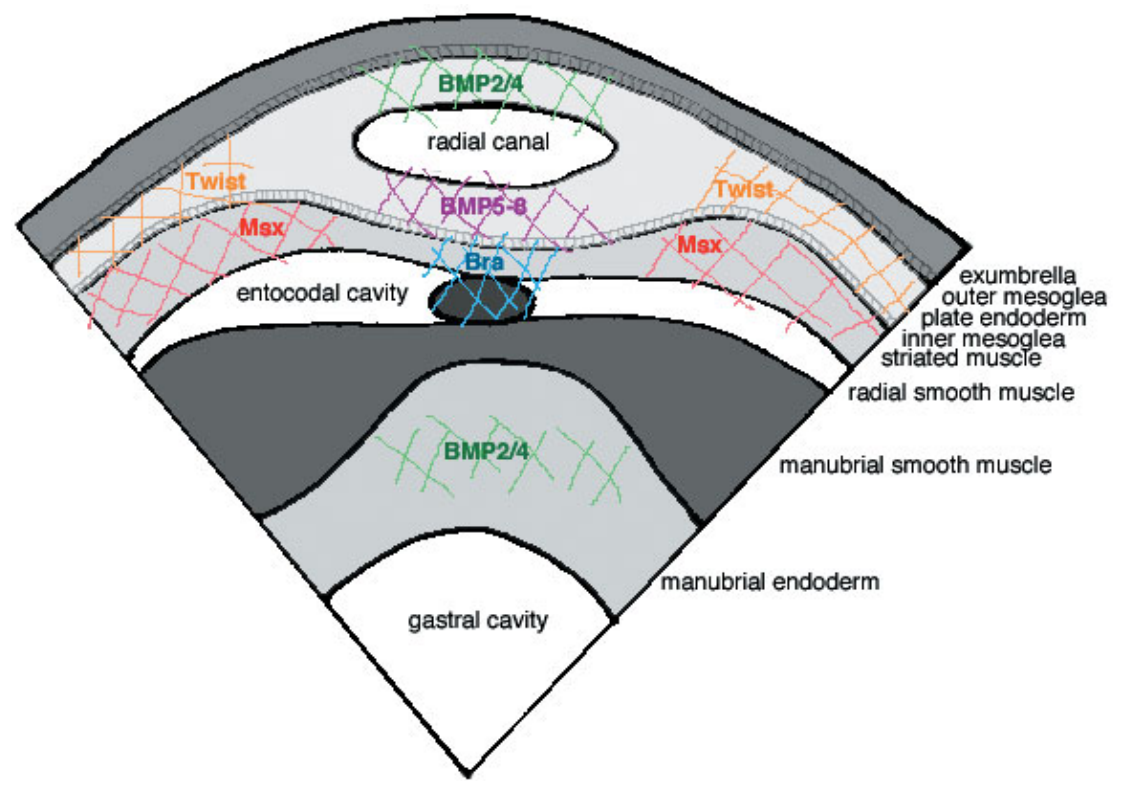

Fig. 5. Gene expression territories in the developing medusa. Schematic representation of in situ staining patterns in a quarter cross section of medusa bud stage 6-7. More detailed expression patterns for mesodermal genes are published for Twist (Spring et al., 2000), Brachyury (Spring et al., 2002), Msx (Galle et al., 2005) and others (Seipel and Schmid, 2005 and references therein).

$B M P$ transcripts localize in accordance with radial symmetry, indicating that any BMP involvement in axial patterning would be restricted to larval development and absent from medusa development, consistent with a primary bilateral symmetry and a secondary superimposed radial symmetry as previously discussed (Finnerty et al., 2004; Seipel and Schmid, 2005).

Alternatively, the jellyfish larval BMP expression may play a role in neurogenesis as gene expression coincides with the activation of the Atonal-like regulator gene At/1 (Seipel et al., 2004a) and with differentiation of the tyrosine-tubulin nerve net (Groeger and Schmid, 2000). In the old planula larva, the jellyfish BMP2/4transcripts localize to the endoderm (Fig. 3E), consistent with the $B M P 2 / 4$ expression in the sea anemone planula larva, where it may be related to differentiation of the gastrodermis (Finnerty et al., 2004).

\section{Jellyfish BMP genes in mesoderm patterning and vascular system formation}

Mammalian BMPgenes are required for mesoderm patterning and neural crest specification (Zhao, 2003; Tribulo et al., 2003). In the jellyfish both BMPgenes are active in the endoderm of the very early medusa bud stages (Fig. $4 A$ and $D$ ) indicating a role in recruitment of polyp tissues for medusa formation which completes the ontogenetic process (Boelsterli, 1977). These stages are characterized by local cell dedifferentiation and high mitotic activity of the polyp myoepithelia (Boelsterli, 1977; Spring et al., 2000). Additionally both genes are continuously active throughout morphogenesis of the medusa gastrovascular system (Fig. 4 A$\mathrm{F})$ with late divergence of expression territories for $B M P 2 / 4$ in the outer and $B M P 5-8$ in the inner endoderm layer of the radial canals (Fig. 4H, K; Fig. 5). This particular pattern is reminiscent of the dorsal-ventral BMP gradients in vertebrates, where high BMP4 concentrations specify ventral tissues, such as blood and epider- mis, whereas lower concentrations specify lateral tissues, such as pronephros and muscle (Dale and Wardle, 1999). Production of BMP proteins in the endoderm layers of the radial canals is consistent with roles as patterning factors for the striated muscle developing in direct contact to the endoderm layer and possibly also for the radial smooth muscles located over the radial canals. Thus, the jellyfish BMPs may induce muscle specific genes in the adjacent developing muscle tissues (Fig. 5), in particular the Brachyuryand Msxgenes (Spring et al., 2002; Galle et al., 2005). A similar situation is found in mammals where BMP4 activates the mesoderm marker Brachyury (Winnier et al., 1995) and the Msx1 gene during neural crest induction (Tribulo et al., 2003). Furthermore the radial canals appear to be directly patterned by the jellyfish BMPs activating the VEGFand VEGFRgenes which are involved in tentacle and gastrovascular canal formation (Seipel et al., 2004c). Recently a direct link between a BMP factor, in this case BMP5-8 and tentacle formation has also been found in Hydra polyps (Reinhardt et al., 2004). Again, a similar situation is also found in mammals where BMP4 and TGF-beta1 activate the VEGF and VEGFR genes in endothelial cells (Bostrom et al., 2004; Park et al., 2004).

While the expression patterns of the BMP and Brachyury genes in medusa development to some extent relate to the patterns of cognate bilaterian genes during gastrulation, the larval expression patterns with Brachyury at the gastrulating posterior pole (Spring et al., 2001) and the BMPs at the anterior pole (Fig. 3) do not match the patterns for bilaterian gastrulation. This may be attributed to the evolutionary introduction of the polyp stage into the life cycle of a preexisting jellyfish ancestor with direct development thereby splitting medusa development at gastrulation, with the first part consisting of larva and polyp formation separated from the second part with entocodon (mesoderm-like layer) development in the differentiating medusa as previously 
A

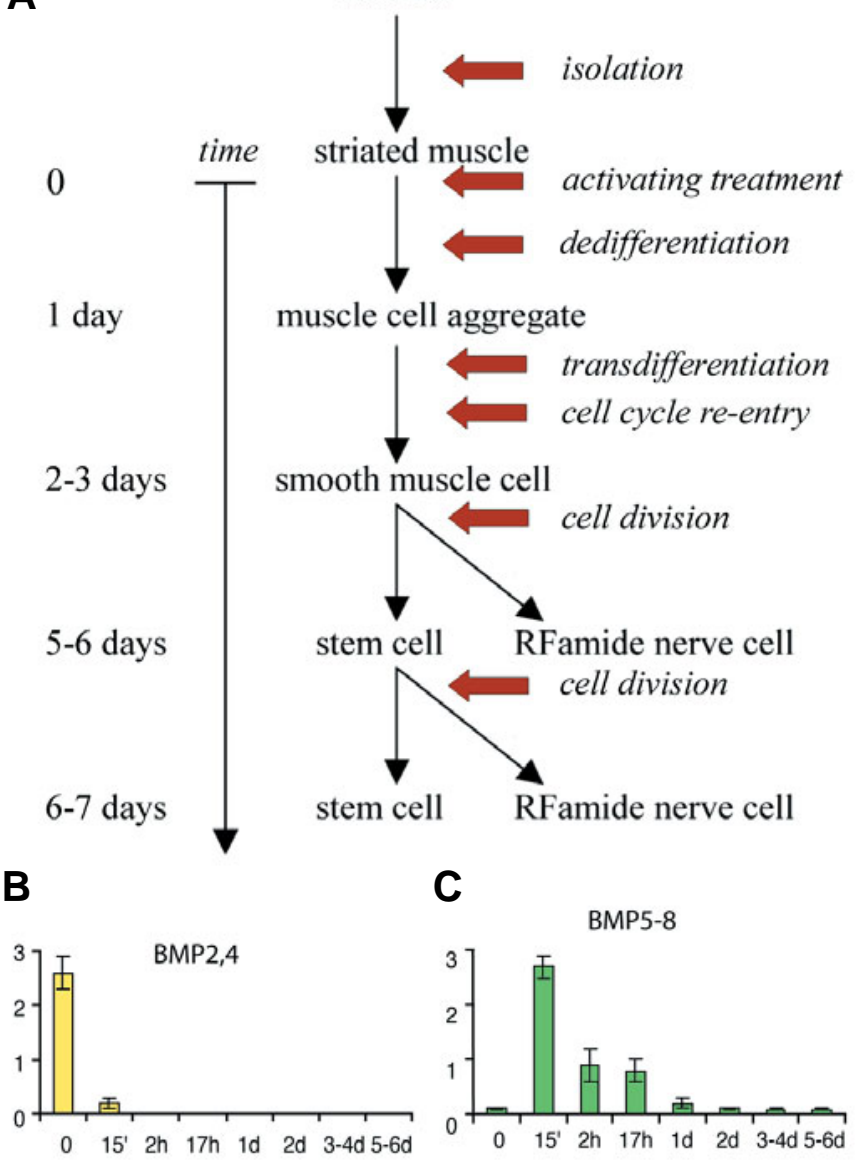

Fig. 6. BMP expression analysis during in vitro transdifferentiation. Flow chart and time course of transdifferentiation experiment (A). Isolated striated muscle of Podocoryne carnea can be activated by enzyme treatment to undergo transdifferentiation. The striated muscle cells transdifferentiate to proliferating smooth muscle cells and terminally differentiated RFamide neuropeptide positive nerve cells. Quantitative RT-PCR expression analysis (B) in isolated striated muscle during activation (0-15 min.), in dedifferentiation (2 hours-1day), during proliferation and transdifferentiation to smooth muscle and nerve cells (1-6 days). The ordinate values are relative expression levels normalized to the expression level of $\mathrm{EF} 1 \alpha$ and displayed in arbitrary units. Time point 0 displays expression in the stable, mechanically isolated striated muscle. discussed (Seipel and Schmid, 2005).

\section{Jellyfish BMP genes and extracellular matrix synthesis}

The bone and cartilage inducing activities of the vertebrate bone morphogenetic proteins were discovered over 30 years ago. The jellyfish equivalent of bone and cartilage is the gelatinous material in the medusa bell, the colloquial jelly, specified as inner and outer mesoglea, i.e. the extracellular matrix on the inside and outside of the endoderm plate (Fig. 5). The jellyfish BMPgenes are expressed in both endodermal layers of the medusa bell. In later bud stages transcripts are also present in the exumbrella (Fig. 4I), the striated muscle (Fig. 4L) and the manubrial lips (Fig. $4 \mathrm{~L}$ ). All bell layers including the endoderm, striated muscle and exumbrella are candidate sources for production of mesoglea layers which in many jellyfish species display sophisticated fibril- lar morphologies based on proteins similar to bilaterian matrix components (Reber-Müller et al., 1995; Schmid et al., 1999). In analogy to the vertebrates it is likely that the jellyfish BMP factors activate ECM production in the medusa bell layers. Moreover, as discussed below, $B M P$ gene activity is related to the integrity of the cell-ECM complex.

\section{Jellyfish BMP genes and transdifferentiation}

Both jellyfish $B M P$ genes respond rapidly to the disruption or degradation of the extracellular matrix (ECM) during isolation or enzymatic activation of the striated muscle tissue. Expression levels of the $B M P 2 / 4$ gene are very high in the mechanically isolated striated muscle (Fig. 6B). Under activation conditions transcripts can be detected up to 15 minutes after activation of the dedifferentiation process. As there is no BMP2/4expression in the undisturbed striated muscle in vivo (Fig. 4I) the immediate and transient BMP2/4 expression in the isolated muscle (Fig. 6B) may reflect a stress response caused by the wounding and excision process.

The BMP5-8gene, on the other hand, appears to be unaffected by wounding and excision as the striated muscle expression levels are comparably low both in vivo (Fig. 4L) and in the mechanically isolated tissue (Fig. 6C). However, BMP5-8 is rapidly activated in response to the ECM degrading enzymatic treatment and thus possibly involved in the dedifferentiation process. Dedifferentiation and transdifferentiation can be activated by various treatments affecting the ECM-receptor signaling pathways, e.g. collagenase and pronase, PKC activators, actin disrupting substances, or, most significantly, by simply grafting mesogloea (ECM) onto mechanically isolated striated muscle thereby causing alterations in the cell-substrate complex (reviewed in Schmid and Reber-Mueller, 1995). Tissue remodelling enzymes like collagenases and proteases affect the ECM, cellsubstrate and cell-cell interactions mediated by integrin complexes in vertebrates (Damsky and Ilic, 2002) and in the jellyfish (Reber-Müller et al., 2001). A large number of growth factors including the TGF $\beta$ superfamily have been found to associate with ECM and can be induced to be released from this matrix storage (Taipale and Keski-Oja, 1997). Growth factors, in turn, control cell proliferation and differentiation, as well as synthesis and remodeling of the ECM. In the jellyfish experimental system BMP5-8 gene activity is highest shortly after enzymatic treatment of the isolated muscle and transcription is maintained at significant levels in the first $17 \mathrm{hrs}$ of transdifferentiation, when expression of muscle specific genes like Msx (Galle et al., 2005) and Tpm2 (Seipel et al., 2004a) is shut down before cell morphology and cycle status are changed. The prolonged BMP5-8 expression may reflect a continuous BMP5-8 growth factor requirement for the early stages of the transdifferentiation process before upregulation of the stem cell gene Ciwi(Seipel etal., 2004b). Thus BMP5-8 may be involved in dedifferentiation, nuclear reprogramming or S-phase re-entry.

\section{Materials and Methods}

\section{Animals and tissues}

Podocoryne carnea M. Sars (Cnidaria, Hydrozoa) are reared in artificial seawater. Medusa parts and buds were obtained by microsurgery and the buds were staged according to Frey (1968). For 
transdifferentiation assays striated muscle tissue was isolated and activated as described (Galle et al., 2005). Larvae were obtained as described (Seipel et al., 2004a,c). Larvae were harvested in age cohorts at two hour intervals post fertilization. Medusa developmental stages were collected by cutting single gonozoid polyps from the colony.

\section{Molecular cloning and phylogenetic analysis}

Molecular biology procedures were performed according to standard protocols. Homology PCR was conducted using the following degenerate primers: BMP2/4F (5'-TGG AAC GAY TGG ATH GTN GCN CC-3'), BMP2/4R1 (5'-TTG AAT TTA ACG RCA NCC RCA NCC-3'), BMP2/4R2 (5'-TGT AGT GTT GTN GGN ACR CAR CA-3), BMP5-8F1 (5'-TGG RAN RAY TGG ATH RTN GCN CC-3'), BMP5-8F2 (5'-GCN TWY TWY TGY CAY GGN RAN TG-3'), BMP5-8R1 (5'-GTN GGN DSR CAR CAN DVY TTN GGN AC-3'), BMP5-8R2 (5'- ARR GTY TGN ACR ATR GCR TGR TT-3'). Full-length sequences were obtained by RACE (rapid amplification of CDNA ends) on cDNA prepared from medusa and gonozoid polyadenylated RNA or by screening a cDNA library as described (Müller et al., 1999). The sequences have been submitted to the DNA databases with GenBank accession DQ145800 and DQ145801. Nucleotide and deduced amino acid sequences were analyzed using the GCG software package. BLAST searches (Altschul et al., 1997) were performed using the NCBI BLAST network service @ http://www.ncbi.nlm.nih.gov. Multiple sequence alignments were generated with MUSCLE (Edgar, 2004) and Clustal X (Jeanmougin et al., 1998). Phylogenetic trees based on the neighbour-joining method were generated with TREEPUZZLE (Schmidt et al., 2002). Accession numbers for published protein sequences used in Fig. 1 are as follows: BMP2/4-Am, AAM54049; BMP2-Hs, CAB82007; BMP3-Hs, P12645; BMP4-Hs, BAA06410; BMP5-Hs, CAC12765; BMP6Hs, CAl19472; BMP7-Hs, CAB90273; BMP8-Hs, P34820; BMP10-Hs, AAC77462; BMP58-Hv, AAS01764; DPP-Dm, AAC47552; DPP-Nv, AAR27580; Gbb-Dm, Q24735; Scr-Dm, AAA56872.

\section{Expression analysis by RT-PCR and in situ hybridization}

Expression analysis by RT-PCR and in situ hybridization was performed as described (Galle et al., 2005). The following primer-sets were used for PCR: BMP2/4F (5'-CGT CGT GAT ACA AGC TCA CAA GAA-3'), BMP2/4R (5'-CAA CGA CAG CCA CAA CCA AGT GC-3'), BMP5-8F (5'GCT TTC AAA GAT CTT GGT TGG TC-3') and BMP5-8R (5'-GCA GTC ATT CAC CAC CAT GTT AGC-3'). Elongation factor 1 alpha was used as a reference to compensate for variations in quality and quantity of the preparations.

DNA templates for in situ probe synthesis were prepared with the primer pairs BMP2/4F (5'-GTC TGT TTG TTC TTC ACT TCG TG-3') and BMP2/4R (5'-GGC ACA CTT CTA GCC GGA CTA G-3') or BMP5-8F (5'CAA GCG GGA AGT TCG TTA CC-3') and BMP5-8R (5'-CAC ACC ATC GTG TTA CTG ACC-3'). In situ hybridization was carried out with both sense and antisense probes. Immunostaining of the hybridized preparations yielded specific signals for the antisense probes only.

\section{Acknowledgments}

This work was supported by the Swiss National Science Foundation.

\section{References}

ALDER, H. and SCHMID, V. (1987). Cell cycles and in vitrotransdifferentiation and regeneration of isolated, striated muscle of jellyfish. Dev. Biol. 124: 358-69.

ALTSCHUL, S.F., MADDEN, T.L., SCHAFFER, A.A., ZHANG, J., ZHANG, Z., MILLER, W. and LIPMAN, D.J. (1997). Gapped BLAST and PSI-BLAST: A new generation of protein database search programs. Nucleic Acids Res. 25: 33893402.

BOELSTERLI, U., (1977). An electron microscopic study of early developmental stages, myogenesis, oogenesis and cnidogenesis in the Anthomedusa, Podocoryne carnea. M. Sars. J. Morphol. 154, 259-289.
BOSTROM, K., ZEBBOUDJ, A.F., YAO, Y., LIN, T.S. AND TORRES, A. (2004) Matrix GLA protein stimulates VEGF expression through increased transforming growth factor-beta1 activity in endothelial cells. J. Biol. Chem. 279: 5290452913.

BOUILLON, J., 1993. Classe des hydrozoaires, in: Grassé, P.-P. (Ed.), Traité de Zoologie. Cnidaires, Cténaires, Vol. III, Fascicule 2, Masson, Paris, pp. 29-416.

DALE, L. AND WARDLE, F.C. (1999). A gradient of BMP activity specifies dorsalventral fates in early Xenopus embryos. Semin. Cell Dev. Biol. 10:319326.

DAMSKY, C.H. AND ILIC, D. (2002). Integrin signaling: it's where the action is. Curr. Opin. Cell Biol. 14:594-602.

EDGAR, R.C. (2004) MUSCLE: multiple sequence alignment with high accuracy and high throughput. Nuc. Acids Res. 32: 1792-1797.

FINNERTY, J.R., PANG, K., BURTON, P., PAULSON, D. AND MARTINDALE, M. Q. (2004). Origins of Bilateral Symmetry: Hox and Dpp expression in a sea anemone. Science 304: 1335-1337.

FREY, J. (1968). Die Entwicklungsleistungen der Medusenknospen und Medusen von Podocoryne carnea M. Sars nach Isolation und Dissoziation. Wilhelm Roux Arch. 160: 428-464.

GALLE, S., YANZE, N. AND SEIPEL, K. (2005). The homeobox gene Msx in development and trans-differentiation of the jellyfish striated muscle. Int. J. Dev. Biol. 49: 961-967

GALLIOT, B. AND SCHMID, V. (2002). Cnidarians as a model system for understanding evolution and regeneration. Int. J. Dev. Biol. 46: 39-48.

GROEGER, H. AND SCHMID, V. (2000). Nerve net differentiation in medusa development of Podocoryne carnea. Sci. Mar. 64, 107-116.

HAYWARD, D.C., SAMUEL, G., PONTYNEN, P.C., CATMULL, J., SAINT, R., MILLER, D.J. AND BALL, E.E. (2002). Localized expression of a dpp/BMP2,4 ortholog in a coral embryo. Proc. Natt. Acad. Sci. USA 99: 8106-8111.

HOBMAYER, B., RENTZSCH, F. AND HOLSTEIN, T.W. (2001). Identification and expression of HySmad1, a member of the R-Smad family of TGFbeta signal transducers, in the diploblastic metazoan Hydra. Dev. Genes Evol. 211:597602.

HOLSTEIN, T.W., HOBMAYER, E. AND TECHNAU, U. (2003). Cnidarians: an evolutionarily conserved model system for regeneration? Dev Dyn. 226:257-67.

JEANMOUGIN, F., THOMPSON, J.D., GOUY, M., HIGGINS, D.G. and GIBSON, T.J. (1998). Multiple sequence alignment with Clustal X. Trends Biochem. Sci. 23: 403-405.

KINGSLEY, D.M. (1994). The TGF-beta superfamily: new members, new receptors and new genetic tests of function in different organisms. Genes Dev. 8, 133146.

MASSAGUE, J. (1998). TGF-beta signal transduction. Ann. Rev. Biochem. 67:753791.

PADGETT, R.W, WOZNEY, J.M. AND GELBART, W.M. (1993). Human BMP sequences can confer normal dorsal-ventral patterning in the Drosophila embryo. Proc. Natl. Acad. Sci. USA 90: 2905-2909.

PARK, C., AFRIKANOVA, I., CHUNG, Y.S., ZHANG, W.J., ARENTSON, E., FONG, G.G., ROSENDAHL, A. AND CHOI, K. (2004). A hierarchical order of factors in the generation of FLK1- and SCL-expressing hematopoietic and endothelial progenitors from embryonic stem cells. Development 131:2749-2762.

REBER-MUELLER S, SPISSINGER T, SCHUCHERT P, SPRING J AND SCHMID V. (1995). An extracellular matrix protein of jellyfish homologous to mammalian fibrillins forms different fibrils depending on the life stage of the animal. Dev. Biol. 169:662-72.

REBER-MUELLER S, STUDER R, MULLER P, YANZE N AND SCHMID V. (2001) Integrin and talin in the jellyfish Podocoryne carnea. Cel/ Biol. Int. 25:753-69.

REINHARDT, B., BROUN, M., BLITZ, I.L. AND BODE, H.R. (2004). HyBMP5-8b, a BMP5-8 orthologue, acts during axial patterning and tentacle formation in Hydra. Dev. Biol. 267: 43-59.

SAMPATH, T.K., RASHKA, K.E., DOCTOR, J.S., TUCKER, R.F. AND HOFFMANN, F.M. (1993). Drosophila transforming growth factor beta superfamily proteins induce endochondral bone formation in mammals. Proc. Natl. Acad. Sci. USA. 90:6004-6008.

SAMUEL G, MILLER D AND SAINT R. (2001). Conservation of a DPP/BMP signaling pathway in the nonbilateral cnidarian Acropora millepora. Evol Dev. 


\section{S. Reber-Müller et al.}

3:241-250.

SCHMID, V. AND ALDER, H. (1984). Isolated, mononucleated, striated muscle can undergo pluripotent transdifferentiation and form a complex regenerate. Cel/38: 801-809.

SCHMID, V. AND REBER-MUELLER, S. (1995). Transdifferentiation of isolated striated muscle of jellyfish in vitro: the initiation process. Semin. Cel/ Biol. 6: 109116.

SCHMID, V., ONO, S.I. AND REBER-MUELLER, S. (1999). Cell-substrate interaction in cnidaria. Microsc. Res. Tech. 15, 44, 254-268.

SCHMIDT, H.A., STRIMMER, K., VINGRON, M. AND VON HAESELER, A. (2002). TREE-PUZZLE: maximum likelihood phylogenetic analysis using quartets and parallel computing. Bioinformatics 18: 502-504.

SEIPEL, K. AND SCHMID, V. (2005). Evolution of striated muscle: Jellyfish and the origin of triploblasty. Dev. Biol. 282: 14-26.

SEIPEL, K., YANZE, N. AND SCHMID, V. (2004a). Developmental and evolutionary aspects of the basic helix-loop-helix transcription factors Atonal-like1 and Achaete-scute homolog 2 in the jellyfish. Dev. Biol. 269: 331-345.

SEIPEL, K., YANZE, N. AND SCHMID,V. (2004b). The germ line and somatic stem cell gene Cniwi in the jellyfish Podocoryne carnea. Int. J. Dev. Biol. 48: 1-7.

SEIPEL, K., EBERHARDT, M., MÜLlER, P., PESCIA, E., YANZE, N. AND SCHMID, V. (2004c). Homologs of vascular endothelial growth factor and receptor, VEGF and VEGFR, in the jellyfish Podocoryne carnea. Dev. Dyn. 231: 303-312.

SPRING, J., YANZE, N., MIDDEL, A.M., STIERWALD, M., GRÖGER, H. AND SCHMID,V. (2000). Ancestral role of the mesoderm specification factor Twist in the life cycle of jellyfish. Dev. Biol. 228: 363-375.

SPRING, J., YANZE, N., JÖSCH, C., MIDDEL, A.M., WINNINGER, B. AND SCHMID, V. (2002). Conservation of Brachyury, Mef2 and Snailin the myogenic lineage of jellyfish: a connection to the mesoderm of Bilateria. Dev. Biol. 244: 372-384.

TAIPALE, J. AND KESKI-OJA, J. (1997). Growth factors in the extracellular matrix. FASEB J. 11: 51-59.

TARDENT, P. (1978). Coelenterata, Cnidaria, in: Seidel, F. (Ed.), Morphogenese der Tiere, Gustav Fischer Verlag, Jena, pp. 83-289.

TRIBULO, C., AYBAR, M.J., NGUYEN, V.H., MULLINS, M.C. AND MAYOR, R. (2003). Regulation of $M s x$ genes by a Bmp gradient is essential for neural crest specification. Development 130: 6441-52.

WINNIER, G., BLESSING, M., LABOSKY, P.A. AND HOGAN, B.L. (1995). Bone morphogenetic protein-4 is required for mesoderm formation and patterning in the mouse. Genes Dev. 9: 2105-2116.

YANZE, N., SPRING, J., SCHMIDLI, C. AND SCHMID, V. (2001). Conservation of Hox/ ParaHox-related genes in the early development of a cnidarian. Dev. Biol. 236: 89-98.

ZHAO, G.Q. (2003). Consequences of knocking out BMP signaling in the mouse. Genesis 35, 43-56.

Received: August 2005

Reviewed by Referees: October 2005

Modified by Authors and Accepted for Publication: November 2005 